\title{
SUSTAINABILITY IN HEALTH SAFETY MANAGEMENT
}

\author{
Magdalena BSOUL-KOPOWSKA; Agata PRZEWOŹNA-KRZEMIŃSKA
}

Częstochowa University of Technology/ Faculty of Management,

Deputy Head of the Department of Sociology, Psychology and Communication in Management

\begin{abstract}
In the face of today's pandemic challenges, human life and health is an asset of particular importance. The basic assumption of every modern state is to protect life by providing its citizens not only with adequate health conditions but above all with a sense of health safety. In addition to safety, health is a fundamental value that should be pursued throughout life. This article presents selected activities of public authorities concerning health policy in the field of health safety with the example of the Silesian Voivodeship. These activities take place in accordance with the principles of sustainable development. The analysis of documents related to direct actions in the field of the discussed problems was used as a research method to explore the problems of health safety in the context of sustainability.

Purpose: This paper aims to analyze and the present selected activities of public authorities concerning health policy in the field of health safety with the example of the Silesian Voivodeship

Design/methodology/approach: The research method was the analysis of documents Findings: The analysis of the existing materials, EU projects, and national health policy revealed that the improvement of population health strengthens sustainable development, whereas sustainable development improves health in a cycle supported by an efficient health system.
\end{abstract}

Key words: health safety, health policy, health care, sustainable development.

\section{Introduction}

The concept of the state is defined as a structure designed not only to last but, importantly, to develop in society. Human life and health are values that are strongly interrelated and require special protection due to their value, which is independent of other legally protected goods. Health is a supreme value, which should be cared for throughout life, as reflected by a high level of health safety culture, which is expressed through the identification of health needs and taking action for health. According to the theoreticians dealing with the issues of public health, the maintenance and improvement of health should take place in accordance with the principles of sustainable development, i.e. satisfying current needs without compromising the ability of future generations to meet their own needs. The basic role of every modern country is to protect life as a manifestation of the biological human existence through creating and providing people with good health conditions and health safety.

Based on the events observed in 2020 and early 2021, a number of public institutions have presented statistical data that indicate the need to modify plans to maintain stability and gradually increase public financing of the health care system

https://doi.org/10.11118/978-80-7509-820-7-0271 
and safety of citizens in the context of the principles of sustainable development. Health care management has become a priority area of government administration. Therefore, health safety is more and more often included in European safety and health programs.

Health safety is defined as a process that allows every person to increase their influence on their health in terms of improving and maintaining good health status ${ }^{3}$ (Taranowicz 2010, p.23). Activities of not only individuals but the entire communities are needed in order to ensure physical, mental, and social well-being. Consequently, health safety should be considered from the standpoint of knowledge and resources that humans can utilize in everyday life. Citizens' sense of health safety is determined primarily by the availability of medical services. The basis for health policies that impact health safety in the EU is to implement health promotion policies. Therefore, in accordance with the Article 168 of the Treaty on the Functioning of the European Union, the achievement of a higher level of health protection is one of the most important objectives of the European Union within all European policies and activities. Current EU health policy aims to improve public health, prevent diseases and threats and combat major epidemics, whereas in the current situation, it is the fight against the global COVID - 19 pandemic and the logistical management of the coronavirus vaccination program. It is critical to provide information and promote it through social campaigns and pro-health programs. Poland's accession to the EU made it necessary not only to introduce but also to comply with all EU standards.

The aim of this paper is to present the activities within health policy in terms of health security with the example of the Silesian Voivodeship using the presentation of selected EU programs, as an example of the actions of public authorities implementing the principles of sustainable development. This term was defined and presented in 1987 by G. Brundtland in the report Our Common Future (World Commission on Environment and Development). This concept was clarified in two documents adopted in 1992 at the United Nations Conference on Environment and Development in Rio de Janeiro. (Declaration on Environment and Development, Agenda 21: Earth Summit Conference). These documents formulate the recommendations for states and organizations on specific problems to be solved in the implementation of sustainable development (e.g. combating poverty, demographic dynamics, human health protection, environmental protection, management of earth surface resources, waste management, etc.), and are the basis for international, global and regional (cross-border) legislation defining the strategy for sustainable development in a given place (country, region, economic sector, institution). As noted in the paper's abstract, document analysis was used as a research method for the purposes of the study, conducted in 2019-2021. The aim of 
the research was to find an answer to the following research question: which health and EU programs are implemented in the Silesian Voivodeship.

\section{Health safety: the origins of health protection activities}

The origins of health care activities can be traced back to ancient Greece when Hippocrates stated that the health of a population was closely related to the environmental conditions in which people lived (Miller et al.202, p.547). It was not until the 19th century (due to the discovery of the microscope in the 16th century) that the sciences of microbiology and bacteriology were established.

In 1848, the General Board of Health was established in London to investigate the causes of the high mortality that persisted among the inhabitants of the great cities following the cholera pandemic. In 1851, the founding International Health Conference was held in Paris to exchange information on epidemic diseases. Research initiated by this Conference led to the establishment of the International Health Organization in Paris in 1907, which became the predecessor of the currently existing World Health Organization, referred to by the abbreviation WHO, which is a specialized organization of the United Nations (established in 1948 with its headquarters in Geneva) (Bsoul-Kopowska 2016, p.250).

These examples of organized collective efforts to combat epidemics of infectious diseases led to the invention of efficient vaccines, implementation of mass immunization programs, and containing the spread of epidemics where they were used (Davies 2010, pp. 624-626). Experience gained in the successful fight against epidemics was taken into account when, at the end of the twentieth century, the science of safety emerged, dealing with, among other things, the identification of existing and potential threats and the possibilities of elimination of their consequences. Therefore, human health and life have been the most important problem and dilemma of mankind for centuries. Therefore, national and international entities performing public administration tasks are obliged to protect life and health.

\section{Health safety in EU policies}

The European Union plays a critical role in improving public health, preventing and treatment of diseases, reducing the number of sources of hazards to human health, and alignment of health strategies between member states. The EU has successfully implemented a comprehensive policy in this area using the Health for Growth programme for 2014-2020. The current institutional structure of the EU supporting the implementation of this policy is formed by the European Commission's Directorate-General for Health and Food Safety and specialized agencies, mainly European, e.g. the Centre for Disease Prevention and Control and the European Medicines Agency (https://ec.europa.eu/health/policies/overview_pl). EU health policy works in parallel with the national policies of individual member states to 
ensure that all people in the EU have access to high-quality health care. The Community activities complement national policies. European health policy involves the development of joint competencies with the member states and the supplementation of national policies ${ }^{4}$. Poland's accession to the EU allowed for the implementation of all EU strategies aimed to improve health safety and the use of EU subsidies. The EU funds made it possible to develop and implement projects presented in Table 1.

Table 1. Examples of EU health projects

\begin{tabular}{|c|c|}
\hline Project aim & Project description \\
\hline $\begin{array}{l}\text { comprehensive prevention programmes for professional } \\
\text { groups }\end{array}$ & $\begin{array}{l}\text { reduction of occupational } \\
\text { diseases }\end{array}$ \\
\hline $\begin{array}{l}\text { comprehensive preventive programmes after a long } \\
\text { absence of employees due to occupational diseases }\end{array}$ & $\begin{array}{l}\text { helping workers with } \\
\text { occupational diseases return } \\
\text { to work }\end{array}$ \\
\hline professional training for nurses and midwives & bridging studies \\
\hline $\begin{array}{l}\text { Professional training for physicians, paramedics, and } \\
\text { medical emergency dispatchers in the area of emergency } \\
\text { medical services. }\end{array}$ & bridging studies \\
\hline $\begin{array}{l}\text { specialization of medical professionals with deficit } \\
\text { specializations: oncologists, cardiologists, and } \\
\text { occupational physicians. }\end{array}$ & medical specialization \\
\hline $\begin{array}{l}\text { professional nursing of the emergency medical services } \\
\text { system }\end{array}$ & postgraduate education \\
\hline $\begin{array}{l}\text { training of employees and managers of hospitals; support } \\
\text { of the accreditation of health care facilities,training of } \\
\text { National Health Fund managers, the staff of founding } \\
\text { bodies, development of qualification standards for } \\
\text { managers in the health care sector. }\end{array}$ & $\begin{array}{l}\text { topics: management, tools } \\
\text { for restructuring and } \\
\text { consolidation of health care } \\
\text { institutions, and accounting }\end{array}$ \\
\hline
\end{tabular}

Source:M. Warchoł, Dotacjeunijne w latach 2007-2013 a system ochronyzdrowia w Polsce, Journal of Education, Health and Sport 7 (5), pp. 401-409.

\section{Management of health of the inhabitants in the Silesian Voivodeship}

The Silesian Voivodeship can be defined as a specific area in Poland due to historical and environmental conditions, facing challenges connected with a high population density and negative demographic forecasts.

There were 4.635 million people living in the Silesian Voivodeship as of July 2019 , which accounts for $12.14 \%$ of the country's population. The urban population is also decreasing, while the rural populationin terms of the number of people per $1 \mathrm{~km}^{2}$ in Poland is on the increase (368 people $/ \mathrm{km}^{2}$ in 2019 according to the statistics of the Central Statistical Office). The Silesian Voivodeship is the most urbanized (77\% of the urban population) and the most densely populated region in Poland. The 
population of the Silesian Voivodeship is also characterized by higher dynamics of population aging than observed nationwide, which is mainly caused by low birth rates and lower female fertility. Environmental factors also play an important role, including high emissions of dust and gas pollutants (2nd and 3rd place in the country), land degradation resulting from the high level of economic use of the voivodeship's resources, and long-term activity of industries that adversely affect both the environment and the health of residents (Priorytety 2019).

Based on the analysis of the value of the average life expectancy of a newborn at birth, the data concerning the health of the inhabitants of the Silesian Voivodeship are among the worst in the country. The comparison of premature mortality rates (0- 64 years) compared to nationwide parameters is also unfavorable. The actual number of deaths per 100,000 people places the Silesian Voivodeship on the thirdhighest level in the country.In the case of COVID-19 in the Silesian Voivodeship, factors conducive to the occurrence of larger outbreak clusters also include conditions associated with the phenomenon of the depopulated cities and the process of trans-industrialization. The most common causes of death in the Silesian Voivodeship arecardiovascular diseases, malignancies, external causes of morbidity and mortality, digestive and respiratory diseases, and, currently, COVID-19.

The Silesian Voivodeship is characterized by high density with medical infrastructure (a large number of hospitals, hospital beds). However, the highest concentration of health care units can be seen in the area of the Upper Silesian urban complex.The following documents were used to conduct the diagnosis which is an important element of defining the state of the discussed region, its position, and problems: Map of health needs in terms of hospital treatment for the Silesian Voivodeship (Mapapotrzebzdrowotnych),long-term goals resulting from the "Policy paper for health care 2014-2020; National Strategic Framework"(Zdrowieaktualności) and epidemiological demographic indicators, expert knowledge of consultants, and local experience (Priorytety). The data obtained from these documents have been taken into account in the "Priorities for regional health policy in the Silesian Voivodeship". The emphasis was put on " the development of comprehensive and coordinated care in all areas, especially in the field of long-term care, oncology care, mother and child care, psychiatric care, care for the elderly, increasing the quality and comprehensiveness of services in outpatient care, reducing the consequences of the adverse demographic situation"(Priorytety). The established priorities are also in line with the Development Strategy of the Silesian Voivodeship Śląskie 2020+.

There are also Regional Operational Programmers' in the Silesian Voivodeship which were created as a result of many years of observations and analyses. They allowed for the diagnosis of the areas at particular health risks for the Silesian residents and the causes for these risks.

The Regional Operational Programme allowed for co-financing activities aimed at labor activation through proper health care. A package of seven Regional Health 
Programmers' worth nearly $£ 93$ million was developed in 2019. In 2021, some EUfunded projects are worth noting. For example, "Onco-Yoga" project (for oncology patients) consists of supporting and raising awareness of the recovery process that is influenced by the patient himself, using his or her physical activity, healthy diets, and way of thinking.The patient needs not only medical therapy but also psychological and social support. Another project, "Support for anesthesiologists", involves equipping doctors with muscle relaxation modules (NMT). The anesthesiologists using the module will be confident that their patients are safe during the procedure. Supported by EU funds,doctors from the Oncology Centre in Gliwice can treat cancers that have so far been considered incurable, using innovative interventional radiology procedures, whereaspregnant women can be tested for fetal heart rate, pulse, uterine muscle contraction activity, and fetal movements at home.

With EU funds, a portable, fast and ultra-sensitive device for detecting SARSCoV-2 will soon be available in Silesian hospitals. European funds are actively supporting the fight against COVID-19. For example, a project is being implemented to reduce risk factors in the work environment resulting from the contact with a patient infected or potentially infected with the Sars-Cov-2 virus, through securing the employees (e.g. of medical entities and units of the state emergency medical services system) with modern equipment to effectively combat the COVID-19 pandemic. Also noteworthy is the project Silesian Program for Mental Health Protection for 2019-2022, which aims to take extensive measures to promote mental health and prevent mental disorders (related to the pandemic) of the inhabitants of the Silesian Province. The biggest challenges in the context of health care concerning the Silesian Voivodeship include increasing access to specialist medical services, limiting the occurrence of occupational diseases, increasing life expectancy, and slowing down the population aging.

\section{Conclusion}

Identification of the priorities for regional health policy in the Silesian Voivodeship represents an attempt to define more precisely the ways of acting, their effects, the measures of these actions to achieve specific operational objectives and health benefits for the inhabitants of the Silesian Voivodeship. All the priorities mentioned above are guided by a long-term strategic objective, which is to improve the health and quality of life of the Voivodeship population. These priorities define the directions of achieving the objectives. Therefore, it can be expected that their implementation will result in many positive changes in the state of health of the population, including e.g. changes in lifestyles of the population and reduction of inequality in access to health services. The analysis of the statistical data, current documents, implemented EU projects, and health policy objectives leads to the conclusion that these actions are aimed at ensuring universal access to prevention 
and health services and increasing the quality of medical services while maintaining equal rights for all, which will help increase health safety and improve living conditions in the Silesian region despite the fight against the pandemic and the introduction of continuous changes in health care. The region has a number of highlevel health care units equipped with modern specialized medical devices and highlyqualified medical staff. Particular attention should be paid to the most successful facilities in the fields such as oncology, cardiac surgery, rehabilitation, emergency medical services, and burn treatment. Units that deal with these areas of medicine in the region are at the top of national rankings.

Due to the constantly introduced changes as a response to the dynamic pandemic situation in the country, the paper presents only a part of the analysis of the documents related to the problems of health safety management in the Silesian region. However, the analysis of the existing materials, EU projects, and national health policy revealed that the improvement of population health strengthens sustainable development, whereas sustainable development improves health in a cycle supported by an efficient health system. Consequently, the concept of a sustainability model is being developed, in which health plays a role of a factor ensuring the permanence of actions taken.

\section{References}

1. Bsoul - Kopowska M. (2016), Zarzadzenie kryzysowe w polityce bezpieczeństwa Polski Unii Europejskiej, wyd. PCz, Częstochowa.

2. DaviesN.(2010), Rozprawa historyka z historia, Znak.Warszawa.

3. EuropeanCommission, LegislativePackage, http://europa.eu/legislation_summaries/public_health/index_pl.htm (accessed on 14 June 2019).

4. Grossman M., On the concept of health capital and the demand for health, Journal of Political Economy 1972, nr 2; G. Liu [i in.], Income productivity in China: on the role of health, Journal of Health Economics 2008, nr 27.

5. Ikeogu D.O., Uwakwe J.O., Chidolue I.B., ( 2013), The Effect of Health Safety Management in National Development,:Mediterranean Journal of Social Sciences, Vol 4 No 7, Published by MCSER-CEMAS-Sapienza University of Rome.

6. 'Inac H., Guner U., Sarısoy S., "EgitiminEkonomikBuyumeveKalkınma " UzerindekiEtkileri,” Eskisehir Osmangazi “Universitesi ‘IIBF Dergisi, pp. 59-70, 2006.

7. Liu G.G, Dow W.H., FU A. Z., Akin J., Lance P., Income productivity in China: on the role of health, Journal of Health Economics 2010, , nr 27, s. 293-311.

8. Mapa potrzeb zdrowotnych, http://bip.katowice.uw.gov.pl/zdrowie/Mapa_Potrzeb_Zdrowotnych.html (accessed on 11 July 2019).

9. Miller M., Zieliński A., PRZEGLADD EPIDEMIOLILOGICZNY 56 (2002), Zdrowie Publiczne - Misja I Nauka Pdfhttp://www.przeglepidemiol.pzh.gov.pl/pobierzartykul?id=490 (accessed on: 10/05/2019).

10. Ozt"urk N., "Iktisadikalkınmadae gitiminrol"u," SosyoEkonomiDergisi, vol. 1, no. 1, pp. $27-44,2005$. 
11. Priorytety dla regionalnej polityki zdrowotnej http://www.katowice.uw.gov.pl/wydzial/wydzial-zdrowia/priorytety-dla-regionalnejpolityki-zdrowotnej (accessed on 12 July 2019).

12. Sytnik-Czetwertyński J., Cianciara D., 2016.The individual face to face with public health: a conflict of interestsor a conflict of conditions? Journal of Education, Health $\begin{array}{llll}\text { and } \quad \text { Sport, } & \text { eISSN 223-237, 2391-8306. DOI }\end{array}$ http://dx.doi.org/10.5281/zenodo.46590.

13. Taranowicz I. (2010),Zdrowie i sposoby radzenia sobie z jego zagrożeniami. Analiza socjologiczna, OficynaWydawnicza Arboretum, Wrocław.

14. Warchoł M., Dotacjeunijne w latach 2007-2013 a system ochrony zdrowia w Polsce,

15. Journal of Education, Health and Sport 7 (5), pp. 401 409.http://bip.katowice.uw.gov.pl/zdrowie/Mapa_Potrzeb_Zdrowotnych.html(accessed on: 11 July 2019).

16. http://www.zdrowie.gov.pl/aktualnosc-34-2133-

17. Policy_paper_dla_ochrony_zdrowia_na_lata_2014_2020_Krajowe_Strategiczne_Ram y.html(accessed on: 11 July 2019).

18. http://www.katowice.uw.gov.pl/wydzial/wydzial-zdrowia/priorytety-dla-regionalnejpolityki-zdrowotnej.(accessed on 12 July 2019).

19. http://www.katowice.uw.gov.pl/wydzial/wydzial-zdrowia/priorytety-dla-regionalnejpolityki-zdrowotnej. (accessed on 12 July 2019). 